\title{
PENGARUH MODEL PEMBELAJARAN TERHADAP KETERAMPILAN SOSIAL DAN HASIL BELAJAR EKONOMI
}

\author{
Robiatul Adawiyah \\ Universitas Indraprasta PGRI, Jakarta, Indonesia \\ robiatuladawiyah94@gmail.com
}

\begin{tabular}{ll}
\hline Received: & 03 Februari 2021 \\
Revised: & 04 Maret 2021 \\
Accepted: & 16 Maret 2021
\end{tabular}

\begin{abstract}
Model pembelajaran menjadi komponen penting yang menentukan keberhasilan belajar. Salah satu yang umum digunakan adalah model pembelajaran konvensional, serta model pembelajaran kooperatif yang menjadi pilihan lain bagi guru dalam tujuannya meningkatkan keterampilan sosial dan hasil belajar peserta didik. Tujuan dari penelitian ini yaitu untuk mengetahui pengaruh model pembelajaran kooperatif tipe take and give terhadap keterampilan sosial, untuk mengetahui pengaruh model pembelajaran kooperatif tipe take and give terhadap hasil belajar, serta untuk mengetahui pengaruh yang signifikan model pembelajaran kooperatif tipe take and give terhadap keterampilan sosial dan hasil belajar secara multivariat. Metode penelitian yang digunakan eksperimen, dengan jumlah sampel 32 peserta didik kelas eksperimen dan 32 kelas kontrol. Analisis data menggunakan multivariat analisis varian MANOVA. Dari hasil analisis didapat bahwa 1) Terdapat pengaruh yang signifikan model pembelajaran terhadap keterampilan sosial dan hasil belajar ekonomi secara multivariat siswa SMA Swasta di Kota Depok dibuktikan dengan nilai Pillai's Trace, Wilks' Lambda, Hotelling's Trace, dan Roy's Largest Root sig sebesar 0,000 $(<0,05)$ dan $\mathrm{Fh}=12,887$. 2) Terdapat pengaruh yang signifikan model pembelajaran terhadap keterampilan sosial siswa SMA Swasta di Kota Depok dibuktikan dengan nilai sig 0,001 $(<0,05)$ dan $F h=12,222$. 3) Terdapat pengaruh yang signifikan model pembelajaran terhadap hasil belajar ekonomi siswa SMA Swasta di Kota Depok dibuktikan dengan nilai sig 0,004 $(<0,05)$ dan $\mathrm{Fh}=8,710$.
\end{abstract}

Keywords: Model Pembelajaran; Take and Give; Keterampilan Sosial; Hasil Belajar; Ekonomi

(*) Corresponding Author: $\quad$ Adawiyah, robiatuladawiyah94@gmail.com, +62 82178528462

How to Cite: Adawiyah, R. (2021). Pengaruh Model Pembelajaran Terhadap Keterampilan Sosial Dan Hasil Belajar Ekonomi. Research and Development Journal of Education, 7 (1), 158-171.

\section{INTRODUCTION}

Pada dasarnya tingkat keberhasilan belajar-mengajar ditentukan dari banyak aspek seperti kemampuan guru, kemampuan dasar siswa, materi pembelajaran, sarana dan prasarana, aspek psikologis seperti minat, bakat, intelegensi, kemampuan kognitif, motivasi, serta model pembelajaran dan lingkungan yang termasuk kedalam aspek eksternal, semua faktor ini menjadi satu kesatuan yang dapat berpengaruh pada keberhasilan belajar dan tercapainya tujuan belajar-mengajar. Meskipun tujuan dirumuskan dengan baik, bahan ajar sudah disiapkan dengan baik, namun jika model pembelajaran yang digunakan belum efektif maka dapat dipastikan keberhasilan belajar tidak tercapai. Sehingga model pembelajaran menjadi salah satu komponen penting dan menjadi faktor yang memastikan keberhasilan proses belajar.

Salah satu faktor yang menyebabkan tercapainya tujuan pembelajaran atau keberhasilan belajar ditentukan oleh seperti apa proses pembelajaran itu berlangsung 
yang dimana proses paling penting adalah interaksi belajar pada guru dan siswa. Guru yang menyenangkan adalah guru yang memahami kebutuhan peserta didik dalam setiap proses pembelajaran peserta didik dan guru yang mampu memotivasi dan menciptakan antusiasme peserta didik untuk mengikuti seluruh proses belajar mengajar di kelas. Model pembelajaran yang dipraktekkan guru dalam setiap tahapan atau rangkaian pembelajaran akan memengaruhi ketercapaian serta prestasi belajar peserta didik (Priansa, 2017:187). Menurut (Ekawati, 2016:55) selama ini banyak guru menerapkan pembelajaran di kelas dengan menggunakan pendekatan pembelajaran konvensional, bahan ajar pada praktek model pembelajaran konvensional didominasi dengan ceramah yang didapat dari buku dan penjelasan guru. Proses belajar siswa dipengaruhi oleh sumber-sumber yang digunakan tersebut.

Selain itu, masalah lain yang sering terjadi dalam pembelajaran konvensional pada umumnya adalah siswa yang jenuh dengan suasana kelas dan menyebabkan kegiatan belajar tidak efektif karena kelas kurang kondusif. Hal ini karena dalam proses pembelajaran pada umumnya, guru menerapkan model pembelajaran konvensional yang bersifat teacher centered dan guru berperan menerangkan materi pelajaran saja tanpa mengikutsertakan siswa yang membuat suasana tidak efektif dan siswa tidak fokus pada saat proses pembelajaran, serta masalah lainnya yaitu hasil belajar siswa tidak optimal yang disebabkan dari kurang sesuai dan tidak efektifnya proses pembelajaran dengan penerapan model pembelajaran konvensional.

Dalam melaksanakan perannya, para guru dapat menggunakan berbagai macam model belajar. Strategi yang dapat dilakukan adalah pembelajaran aktif (active learning) yang salah satu modelnya adalah pembelajaran kooperatif (cooperative learning) dimana peserta didik sebagai pusat pembelajaran dan tujuannya adalah menciptakan situasi keberhasilan individu ditentukan dan dipengaruhi oleh keberhasilan kelompoknya, selain itu, tujuan lain dari pembelajaran kooperatif adalah meningkatkan hasil belajar akademik, pengakuan adanya keragaman, dan bertujuan mengembangkan keterampilan sosial peserta didik (Priansa, 2017:187).

Keterampilan sosial merupakan salah satu keterampilan yang amat penting untuk dimiliki peserta didik mengingat mereka merupakan makhluk sosial, bagian dari masyarakat, bangsa, dan negara. Keterampilan sosial menjadi bekal bagi mereka untuk dapat berinteraksi, beradaptasi, dan berhubungan baik dengan lingkungannya. Rahayuningtyas (2018) mengungkapkan bahwa yang terjadi di lapangan anak masih kesulitan mengungkapkan perasaannya kepada orang lain dengan cara yang tepat, keterampilan sosial anak-anak masih rendah, dan dalam kegiatan kelompok masih ada siswa yang tidak mau bekerja sama dengan kelompok yang telah ditentukan guru karena mereka lebih senang berkelompok dengan teman yang biasanya bermain dengan mereka. Selain itu, dalam penemuan Lisdiana (2019) menyebutkan banyak aspek keterampilan sosial siswa yang masih tergolong rendah dalam hal : 1) kemampuan berbagi informasi, 2) kemampuan menghargai, 3) kemampuan siswa bersungguh-sungguh untuk belajar, 4) kemampuan bekerja sama, 5) kemampuan menyampaikan pendapat, 6) kemampuan menerima pendapat. Dalam prakteknya, model pembelajaran kooperatif memberikan kesempatan bagi peserta didik untuk bisa meningkatkan keterampilan sosialnya. Huda (2013:45) menjelaskan bahwa sebagai bagian dari kehidupan sosial, kebanyakan proses belajar kita terjadi dalam setting sosial, dalam kelompok-kelompok atau muncul sebagai hasil dari interaksi dengan orang lain.

Selain keterampilan sosial, tujuan dari pembelajaran kooperatif adalah meningkatkan hasil belajar akademik. Sehingga model belajar juga akan berpengaruh terhadap hasil belajar. Dimana hasil belajar adalah perubahan pada ranah psikologis setelah melalui proses belajar. Setidaknya ada 2 (dua) faktor yang memengaruhi prestasi belajar/hasil belajar yaitu faktor internal dan faktor eksternal (Vhalery, 2019), dimana 
dalam faktor eksternal ini salah satunya terdapat aspek non-sosial yaitu model belajar, alat-alat atau media yang digunakan untuk belajar dan tempat belajar. Sehingga faktor ini menjadi cukup kuat dalam menunjang hasil belajar dan dapat pula mempengaruhinya. Salah satu model pembelajaran kooperatif yang bisa diterapkan adalah tipe take and give. Melalui model pembelajaran ini siswa atau peserta didik dapat lebih aktif dan mampu memahami materi yang disampaikan oleh guru, karena dalam pelaksanaan model pembelajaran ini nantinya setiap peserta didik akan diberikan kartu yang berisi materi bahasan terkait pembelajaran yang harus dikuasai masing-masing peserta didik bersama kelompoknya.

Beberapa penelitian yang dilakukan mengenai model pembelajaran tipe take and give adalah melihat bagaimana pengaruhnya terhadap hasil belajar, diantaranya model pembelajaran tipe take and give efektif terhadap peningkatan hasil belajar (Septina, 2018) dan ada pengaruh positif model pembelajaran tipe take and give terhadap hasil belajar (Septiana \& Ningrum, 2017), serta hasil penelitian lain yang sama juga mengungkapkan bahwa model pembelajaran tipe take and give dapat meningkatkan hasil belajar peserta didik (Patonah, 2018). Namun, dari banyak penelitian mengenai model pembelajaran tipe take and give tidak banyak hasil penelitian yang melihat bagaimana pengaruh penerapan model pembelajaran tipe take and give terhadap keterampilan sosial peserta didik. Oleh sebab itu, pada penelitian ini peneliti menggunakan model pembelajaran tipe take and give dan pengaruhnya terhadap keterampilan sosial. Selain itu, peneliti juga menggunakan model pembelajaran tipe take and give terhadap hasil belajar ekonomi siswa.

Tujuan dari penelitian ini adalah untuk mengetahui pengaruh model pembelajaran tipe take and give terhadap keterampilan sosial, untuk mengetahui pengaruh model pembelajaran tipe take and give terhadap hasil belajar, serta untuk mengetahui apakah ada pengaruh yang signifikan model pembelajaran tipe take and give terhadap keterampilan sosial dan hasil belajar secara multivariat.

\section{LITERATURE REVIEW}

\section{Keterampilan Sosial}

Menurut David and Johnson dalam Agusniatih \& Monepa (2019) keterampilan sosial merupakan pengetahuan tentang perilaku manusia dan proses antar pribadi, kemampuan memahami perasaan, sikap, motivasi orang lain tentang apa yang dikatakan dan dilakukannya, dan kemampuan untuk berkomunikasi dengan jelas dan efektif serta kemampuan membangun hubungan yang efektif dan kooperatif. Keterampilan sosial adalah kemampuan berdasarkan pengetahuan untuk menempatkan diri dan mengambil peran melalui interaksi sosial di lingkungan sekitar (Vhalery, R., Sari, \& Yusup, 2020). (Yusuf, M., Tarjiah, I., \& Satibi, O., 2018:125) menjelaskan keterampilan sosial juga sebagai kemampuan untuk berinteraksi dalam lingkungan sosial dengan cara yang tepat, bisa diterima, dan dinilai menguntungkan orang lain.

Keterampilan sosial menjadi hal yang penting dalam bersosialisasi antar sesama manusia, cara dalam melakukan interaksi, baik dalam hal berkomunikasi maupun bertingkah laku dengan orang lain (Lisdiana, 2019:164). Perdani dalam Vhalery, Sari, \& Yusup (2020:64) membagi ciri-ciri keterampilan sosial yaitu: 1) perilaku interpersonal yang merupakan perilaku untuk melakukan interaksi sosial atau keterampilan menjalin persahabatan, 2) perilaku yang berhubungan dengan diri sendiri, 3) perilaku yang berhubungan dengan kesuksesan akademis, 4) keterampilan komunikasi untuk menjalin hubungan sosial yang baik. Kholin, et al., (Putri, 2019:94) 
mengungkapkan bahwa siswa yang memiliki keterampilan sosial baik dapat mengonstruksi personal serta karakter siswa dalam pembelajaran yang dapat mempengaruhi kemampuan akademik dan dapat meningkatkan kreativitas siswa.

Sehingga dapat disimpulkan pentingnya keterampilan sosial dimiliki peserta didik adalah karena mereka sebagai individu-individu akan selalu memiliki perannya di masyarakat, bangsa, dan negara sehingga kemampuan mereka dalam menjalin dan membangun hubungan sosial yang dapat diterima, bernilai, serta membangun hubungan yang baik untuk diri sendiri sebagai individu dan di lingkungan sosial. Indikator keterampilan sosial dalam penelitian ini menggunakan 4 (empat) kategori keterampilan sosial menurut Cartledge \& Milburn dalam Saripah \& Mulyani (2015:153) terdiri atas :

a. Perilaku terhadap lingkungan (environmental behavior)

b. Perilaku interpersonal (interpersonal behavior)

c. Perilaku yang berhubungan dengan diri sendiri (self-related behavior)

d. Perilaku yang berhubungan dengan tugas (task-related behavior)

\section{Hasil Belajar}

Menurut Abidin (2018:13) hasil belajar adalah kemampuan yang diperoleh siswa setelah mengikuti kegiatan belajar berdasarkan tujuan pembelajaran yang telah ditetapkan dan dinyatakan dalam bentuk angka yang diperoleh dari hasil tes setelah menjalani proses pembelajaran. Hasil belajar siswa dapat diketahui setelah diadakan evaluasi, hasil evaluasi memperlihatkan tentang tinggi atau rendahnya hasil belajar siswa. Herawati (2017) menyatakan hasil belajar mempunyai peranan penting dalam proses pembelajaran yang dapat memberikan informasi terhadap guru tentang kemajuan siswa dalam menguasai dan menyerap materi pelajaran sehingga proses penilaian hasil belajar sangat diperlukan dalam upaya mencapai tujuan-tujuan pembelajaran melalui kegiatan belajar. Arifin (2011:303) memaksimalkan proses dan hasil belajar artinya guru melakukan berbagai upaya yang lebih baik dengan tujuan proses belajar bisa berjalan secara efektif dan hasil belajar yang didapat juga optimal. Hasil belajar yang optimal berarti juga melihat dari optimal ketuntasan belajarnya, terampil dalam mengerjakan tugas, dan memiliki apresiasi yang baik terhadap pelajaran. Dapat disimpulkan bahwa hasil belajar adalah ukuran kemampuan siswa atau hasil yang telah dicapai siswa setelah mendapat proses pembelajaran dan mengikuti tahapan proses pembelajaran. Dalam penelitian ini, hasil belajar yang didapat sebagai ukuran apakah dengan model pembelajaran yang diterapkan berpengaruh pada hasil belajarnya.

Hidayat (2013:85) membagi faktor-faktor yang memengaruhi keberhasilan belajar yaitu faktor internal dan eksternal :

a. Faktor internal terdiri dari, aspek fisiologis (jasmaniah) dan aspek psikologis. Kemudian,

b. Faktor eksternal terdiri dari faktor sosial (yaitu hubungan dengan sesama manusia seperti guru, staf sekolah, teman, masyarakat) dan faktor non sosial yaitu segala yang dapat menunjang belajar termasuk media atau alat-alat yang dipakai untuk belajar.

Herawati (2017:108) juga membagi faktor-faktor yang memengaruhi hasil belajar berdasarkan 1) faktor intern, yang meliputi jasmani dan psikologis, dan 2) faktor ekstern, lingkungan keluarga, lingkungan masyarakat, dan lingkungan sekolah termasuk metode mengajar. Begitu juga dengan Priansa (2017:44) yang menyatakan hasil belajar dapat dipengaruhi oleh 1) faktor internal (keadaan/kondisi jasmani dan 
rohani peserta didik) dan, 2) faktor eksternal (kondisi lingkungan sekitar peserta didik), serta faktor pendekatan belajar (approach to learning).

3. Model Pembelajaran

a. Model Pembelajaran Konvensional

Nasution dalam Zulyadaini (2016:155-156) mengungkapkan bahwa model pembelajaran konvensional memiliki ciri-ciri diantaranya :

1) Tujuan tidak dirumuskan secara spesifik dalam bentuk kelakukan yang dapat diamati dan diukur

2) Materi pelajaran diberikan kepada kelompok dan kelas keseluruhan tanpa mencermati pada setiap peserta didik secara individu

3) Materi pelajaran yang disampaikan kepada peserta didik umumnya dalam bentuk ceramah, kuliah, tugas tertulis, dan media lainnya tanpa didiskusikan dengan siswa

4) Mengacu pada aktivitas guru dalam proses mengajar

5) Membuat siswa bersikap pasif karena proses belajar mengajar bersifat teacher centered

6) Kecepatan selama proses belajar mengajar mengikuti dan ditentukan bergantung kepada guru

7) Setelah dilakukan pengujian, baik dalam bentuk ulangan ataupun ujian biasanya baru adanya pemantapan materi kepada siswa

8) Berhasil atau tidaknya proses belajar ditentutkan oleh guru dengan menilai secara subyektif

9) Materi pelajaran hanya dikuasai beberapa murid saja dan sebagian lain tidak menguasai sepenuhnya materi, serta ada pula yang tidak menguasai sama sekali

10) Tugas utama guru sebagai pemberi pengetahuan

11) Evaluasi yang diberikan biasanya setelah materi dipelajari dan ditentukan berdasarkan angka untuk laporan hasil belajar tiap semester

Model pembelajaran konvensional adalah model pembelajaran yang berpusat pada guru, mengutamakan hasil bukan proses, siswa berperan sebagai objek dan bukan subjek pembelajaran yang membuat siswa sulit untuk menyampaikan pendapatnya. Selain itu, metode yang digunakan hanya berfokus pada ceramah, pembagian tugas dan latihan sebagai bentuk pengulangan dan pendalaman materi ajar (Ibrahim, 2017:202).

b. Pengertian Model Pembelajaran Kooperatif Tipe Take and Give

Kooperatif dalam bahasa Inggris disebut dengan "Cooperate", yaitu bekerja sama. Pembelajaran kooperatif merupakan salah satu model pembelajaran kelompok yang memiliki aturan-aturan tertentu, yang berguna untuk membangun hubungan antar peserta didik (Vhalery \& Martiah, 2018; Leksono, Vhalery, \& Maranatha, 2018). Pembelajaran kooperatif merupakan pembelajaran yang menyajikan ide bahwa peserta didik harus mampu melaksanakan kerja sama melalui sebuah tim, menjadi sebuah rangkaian kegiatan belajar mengajar yang lebih bertanggung jawab. Huda (2017:111) mengatakan bahwa salah satu landasan berpikir yang mendasari dikembangkannya pembelajaran kooperatif adalah karena dalam model pembelajaran ini memunculkan rasa kerja sama yang menyebabkan meningkatnya motivasi lebih tinggi daripada menggunakan model pembelajaran yang sifatnya kompetitif individual. Priansa (2017) menyatakan bahwa tujuan model pembelajaran kooperatif secara umum adalah menciptakan situasi 
keberhasilan individu yang ditentukan atau dipengaruhi oleh keberhasilan kelompoknya. Tujuan khusus dari pembelajaran kooperatif yaitu 1) hasil belajar akademik, 2) pengakuan adanya keragaman, 3) pengembangan keterampilan sosial.

Salah satu tipe model pembelajaran kooperatif yaitu siswa atau peserta didik diminta untuk saling berbagi dengan teman kelompoknya yang berkenaan dengan topik pembahasan yang diberikan guru. Model pembelajaran ini melatih siswa untuk aktif dan saling berkolaborasi dalam menyampaikan materi yang diterima, untuk kemudian materi tersebut di transfer kepada teman-teman lainnya secara berulang-ulang. Dalam penerapannya, Model Pembelajaran Cooperative Learning Tipe Take and Give menggunakan media berupa kartu sebagai alat bantu dimana kartu ini berisi materi pelajaran. Peserta didik yang menggunakan media dalam proses belajar seperti alat peraga akan menghasilkan nilai lebih. Media pembelajaran yang digunakan dibuat menarik agar peserta didik dapat memahami dengam mudah materi yang disampaikan (Gayatri, 2017). Jika model pembelajaraan kooperatif tipe take and give diterapkan dalam kegiatan belajar maka diperkiran hasil belajar peserta didik akan mengalami peningkatan karena model pembelajaraan kooperatif tipe take and give merupakan model pembelajaran 'saling memberi dan menerima' sehingga materi benar-benar dikuasai banyak apabila peserta didik mampu mengajarkan pada peserta didik yang lainnya (Patonah, 2018:117).

Dalam Take and Give, siswa diberi kartu yang didalamnya terdapat catatan untuk dihafal dan dikuasai, kemudian setiap siswa mencari teman untuk saling bertukar informasi mengenai materi yang masing-masing mereka dapatkan dalam kartu. Kegiatan pembelajaran diakhiri dengan memberikan evaluasi dimana masing-masing siswa diberi pertanyaan sesuai dengan kartu yang sudah dibagikan kepada masing-masing dan materi yang didapat dari teman-temannya. Tujuan dari model pembelajaran kooperatif tipe take and give ini adalah membangun agar suasana kelas ceria, dinamis, siswa yang aktif, bersemangat, dan antusias, serta menjadikan keadaan selama proses pembelajaran yang jauh dari pasif dan tidak menjenuhkan. Model ini bertujuan agar tujuan pembelajaran dapat tercapai dengan cara yang efektif dan efisien. Strategi Take and Give mempunyai beberapa kelebihan : 1) dapat diubah sesuai dengan kehendak dan kondisi dalam proses pembelajaran, 2) membiasakan siswa untuk bisa saling bekerja sama dan menghargai kemampuan orang lain, 3) membiasakan siswa agar bisa bergaul dan bersosialisasi secara baik dengan teman sekelas, 4) memperdalam dan mempertajam wawasan dan materi yang dipahami oleh siswa dengan media kartu yang dibagikan, dan 5) melatih dan meningkatkan kemampuan siswa untuk dapat bertanggung jawab, karena setiap individu diharuskan untuk memahami materi yang ada pada setiap kartu yang dimiliki (Huda, 2017).

\section{METHODS}

Dalam penelitian ini, yang menjadi objek penelitian adalah SMA Swasta di Depok, yaitu SMA Tadika Petiwi dan SMA Yadika 12 Limo. Jenis penelitian yang dilakukan adalah kuantitatif dengan kuasi eksperimen dengan desain posttest-only control design dimana terdapat dua kelompok yang masing-masing dipilih secara random, kelompok pertama diberi perlakuan $(\mathrm{X})$ disebut kelas eksperimen dan kelompok yang lain tidak, disebut kelompok kontrol (Sugiyono,2012:114). Populasi dari objek yang diteliti adalah 502 peserta didik. Penelitian dilakukan pada siswa kelas XI IPS Semester Genap Tahun Ajaran 2018/2019. Sampel yang digunakan dalam penelitian ini adalah 32 peserta didik 
kelas XI IPS 1 SMA Tadika Pertiwi sebagai kelas eksperimen dan 32 peserta didik kelas XI IPS 2 dari SMA Yadika 12 Limo sebagai kelas kontrol, dengan perlakuan yang berbeda dari masing-masing sekolah.

Teknik pengumpulan data yang dilakukan adalah melalui eksperimen dan kuesioner. Variabel independen yang diteliti adalah variabel A (Model Pembelajaran) dan variabel dependen (Y) (Keterampilan Sosial dan Hasil Belajar). Pengujian instrumen keterampilan sosial yang dilakukan adalah dengan uji validitas dan realibilitas dengan menggunakan korelasi pearson product moment, dan alpha cronbach. Pengujian instrumen hasil belajar menggunakan product moment, Kuder-Richardson 20, Daya Beda, dan Difficulty Index (P).

Teknik pengujian hipotesis menggunakan teknik Multivariate Analysis of Varians (Manova). Sutrisno \& Wulandari (2018:40) menjelaskan bahwa MANOVA mempunyai pengertian sebagai suatu teknik statistik yang digunakan untuk menghitung pengujian signifikansi perbedaan rata-rata secara bersamaan antara kelompok untuk dua atau lebih variabel terikat. Manova memiliki kemiripan asumsi dengan ANOVA tetapi diperluas untuk kasus multivariat, asumsi yang harus dipenuhi yaitu : 1) Independen secara statistik, 2) Sampel acak, 3) Normalitas multivariat, 4) homogenitas matriks kovariansi. Sebelum data dianalisis untuk pengujian hipotesis, dilakukan uji normalitas, uji homogenitas varians, dan uji homogenitas matrik varian kovarian sebagai uji persyaratan analisis data (Mutakin \& Cleopatra, 2015:46-57).

\section{RESULTS \& DISCUSSION}

\section{Pengolahan Hasil Data Penelitian}

Pengumpulan data menggunakan kuesioner yang berisikan masing-masing 30 pertanyaan yang sudah melalui uji instrumen untuk setiap instrumen variabel. Data yang diperlukan dalam penelitian ini diperoleh melalui instrumen kuesioner yang berisikan 30 pertanyaan dan 30 pernyataan dengan pilihan jawaban menggunakan alternatif jawaban. Data yang diperoleh dari penyebaran kuesioner yang merupakan data primer penelitian.

\section{Tabel 1.}

Hasil Statistik Deskriptif Keterampilan Sosial pada Model Pembelajaran Kooperatif Tipe Take and Give

\begin{tabular}{|c|c|c|}
\hline & & $\begin{array}{c}\text { Keterampilan Sosial dengan Model Pembelajaran Kooperatif Tipe } \\
\text { Take and Give }\end{array}$ \\
\hline \multirow{2}{*}{$\mathrm{N}$} & Valid & 32 \\
\hline & Missing & 0 \\
\hline \multicolumn{2}{|c|}{ Mean } & 109,66 \\
\hline \multicolumn{2}{|c|}{ Median } & 107,50 \\
\hline \multicolumn{2}{|c|}{ Mode } & $102^{\mathrm{a}}$ \\
\hline \multicolumn{2}{|c|}{ Std. Deviation } & 14,610 \\
\hline \multicolumn{2}{|c|}{ Skewness } &, 411 \\
\hline \multicolumn{2}{|c|}{ Std. Error of Skewness } & ,414 \\
\hline \multicolumn{2}{|c|}{ Kurtosis } &, 555 \\
\hline \multicolumn{2}{|c|}{ Std. Error of Kurtosis } & ,809 \\
\hline \multicolumn{2}{|c|}{ Range } & 65 \\
\hline \multicolumn{2}{|c|}{ Minimum } & 79 \\
\hline \multicolumn{2}{|c|}{ Maximum } & 144 \\
\hline
\end{tabular}

Sumber : Hasil Output SPSS versi 20

Berdasarkan tabel diatas diketahui skor Keterampilan Sosial dari 32 peserta didik SMA Tadika Pertiwi yang diberikan model pembelajaran kooperatif tipe take and give 
memiliki skor terendah 79 dan skor tertinggi 144. Keterampilan Sosial dengan model pembelajaran kooperatif tipe take and give dari 32 peserta didik tersebut terlihat pada Tabel 1 mempunyai nilai rata-rata 109,66 dan simpangan baku sebesar 14,610. Dari data tabel diatas dapat ditarik kesimpulan bahwa keterampilan sosial peserta didik yang diberikan model pembelajaran kooperatif tipe take and give dalam kategori tinggi.

\section{Tabel 2.}

Hasil Statistik Deskriptif Keterampilan Sosial pada Model Pembelajaran Konvensional

\begin{tabular}{|c|c|c|}
\hline & & $\begin{array}{c}\text { Keterampilan Sosial dengan Model Pembelajaran } \\
\text { Konvensional }\end{array}$ \\
\hline \multirow{2}{*}{$\mathrm{N}$} & Valid & 32 \\
\hline & Missing & 0 \\
\hline \multicolumn{2}{|c|}{ Mean } & 94,38 \\
\hline \multicolumn{2}{|c|}{ Median } & 94,50 \\
\hline \multicolumn{2}{|c|}{ Mode } & 99 \\
\hline \multicolumn{2}{|c|}{ Std. Deviation } & 10,314 \\
\hline \multicolumn{2}{|c|}{ Skewness } &, 329 \\
\hline \multicolumn{2}{|c|}{ Std. Error of Skewness } & ,414 \\
\hline \multicolumn{2}{|c|}{ Kurtosis } & ,405 \\
\hline \multicolumn{2}{|c|}{ Std. Error of Kurtosis } & ,809 \\
\hline \multicolumn{2}{|c|}{ Range } & 49 \\
\hline \multicolumn{2}{|c|}{ Minimum } & 72 \\
\hline \multicolumn{2}{|c|}{ Maximum } & 121 \\
\hline
\end{tabular}

Berdasarkan tabel diatas diketahui skor Keterampilan Sosial dari 32 peserta didik SMA Yadika 12 Limo yang diberikan model pembelajaran konvensional memiliki skor terendah 72 dan skor tertinggi 121. Keterampilan Sosial dengan model pembelajaran konvensional dari 32 peserta didik tersebut terlihat pada Tabel 2 mempunyai nilai ratarata 94,38 dan simpangan baku sebesar 10,314. Dari data tabel diatas dapat ditarik kesimpulan bahwa keterampilan sosial peserta didik yang diberikan model pembelajaran konvensional dalam kategori cukup.

Tabel 3.

Hasil Statistik Deskriptif Hasil Belajar Ekonomi pada Model Pembelajaran Kooperatif Tipe Take and Give

\begin{tabular}{lcc}
\hline & $\begin{array}{c}\text { Hasil Belajar Ekonomi dengan Model Pembelajaran } \\
\text { Kooperatif Tipe Take and Give }\end{array}$ \\
\hline $\mathrm{N}$ & Valid & 32 \\
Mean & Missing & 0 \\
Median & 76,72 \\
Mode & 80,00 \\
Std. Deviation & 80 \\
Skewness & 9,471 \\
Std. Error of Skewness &,- 167 \\
Kurtosis &, 414 \\
Std. Error of Kurtosis & $-1,315$ \\
Range &, 809 \\
Minimum & 30 \\
Maximum & 60 \\
\hline Sumber : Hasil Output SPSS versi 20 & 90
\end{tabular}

Sumber : Hasil Output SPSS versi 20

Berdasarkan tabel diatas diketahui skor Hasil belajar ekonomi dari 32 peserta didik SMA Tadika Pertiwi yang diberikan model pembelajaran kooperatif tipe take and give 
memiliki skor terendah 60 dan skor tertinggi 90. Hasil belajar ekonomi dengan model pembelajaran kooperatif tipe take and give dari 32 peserta didik tersebut terlihat pada Tabel 3 mempunyai nilai rata-rata 76,72 dan simpangan baku sebesar 9,471. Dari data tabel diatas dapat ditarik kesimpulan bahwa hasil belajar ekonomi peserta didik yang diberikan model pembelajaran kooperatif tipe take and give dalam kategori tinggi.

\section{Tabel 4.}

Hasil Statistik Deskriptif Hasil Belajar Ekonomi pada Model Pembelajaran Konvensional

\begin{tabular}{lcc}
\hline & $\begin{array}{c}\text { Hasil Belajar Ekonomi dengan Model Pembelajaran } \\
\text { Konvensional }\end{array}$ \\
\hline $\mathrm{N}$ & Valid & 32 \\
Mean & 0 & 70,16 \\
Median & 70,00 \\
Mode & 75 \\
Std. Deviation & 8,278 \\
Skewness &,- 235 \\
Std. Error of Skewness &, 414 \\
Kurtosis &,- 602 \\
Std. Error of Kurtosis &, 809 \\
Range & 30 \\
Minimum & 55 \\
Maximum & 85 \\
\hline Sumber : Hasil Output SPSS versi 20 &
\end{tabular}

Sumber : Hasil Output SPSS versi 20

Berdasarkan tabel diatas diketahui skor Hasil belajar ekonomi dari 32 peserta didik SMA Yadika 12 Limo yang diberikan model pembelajaran konvensional memiliki skor terendah 55 dan skor tertinggi 85. Hasil belajar ekonomi dengan model pembelajaran konvensional dari 32 peserta didik tersebut terlihat pada Tabel 4 mempunyai nilai ratarata 70,16 dan simpangan baku sebesar 8,278. Dari data tabel diatas dapat ditarik kesimpulan bahwa hasil belajar ekonomi peserta didik yang diberikan model pembelajaran konvensional dalam kategori cukup.

\section{Pengujian Persyaratan Analisis}

1. Uji Normalitas

Tabel 5.

Hasil Perhitungan Uji Normalitas Data

\begin{tabular}{llcc}
\hline & & Keterampilan Sosial & $\begin{array}{c}\text { Hasil Belajar } \\
\text { Ekonomi }\end{array}$ \\
\hline $\mathrm{N}$ & Mean & 64 & 64 \\
Normal Parameters & Std. Deviation & 104,19 & 73,44 \\
& Absolute & 13,583 & 9,423 \\
Most Extreme Differences & Positive &, 136 &, 143 \\
& Negative &,- 136 &, 143 \\
Kolmogorov-Smirnov Z & & 1,089 &,- 132 \\
Asymp. Sig. (2-tailed) & &, 186 & 1,143 \\
Sumber : Hasil Output SPSS versi 20 & &, 147 \\
\hline
\end{tabular}

Sumber : Hasil Output SPSS versi 20

Dari tabel diatas menunjukkan bahwa semua kelompok data yang di uji normalitasnya dengan one-sample kolmogorov-smirnov test dengan SPSS diperoleh kelompok data memberikan nilai signifikansi pada baris Asymp.Sig (2.Tailed) masing-masing menghasilkan nilai sig > 0,05, yaitu Keterampilan Sosial 0,186> 
0,05 dan Hasil Belajar Ekonomi 0,147 > 0,05. Sehingga dapat disimpulkan bahwa dua kelompok data dalam penelitian ini berasal dari populasi yang berdistribusi normal. Hal ini menunjukkan bahwa salah satu prasyarat uji $\mathrm{F}$ dalam penelitian telah terpenuhi.

2. Pengujian Homogenitas Matrik Varian Kovarian

a. Homogenitas Matriks Varians Kovarian

Tabel 6.

Hasil Uji Homogenitas Matriks Varians Kovarian

\begin{tabular}{cc}
\hline & Box's Test of Equality of Covariance Matrices \\
\hline Box's M & 5,414 \\
F & 1,741 \\
df1 & 3 \\
df2 & 691920,000 \\
Sig. &, 156 \\
\hline Sumber : Hasil Output SPSS versi 20
\end{tabular}

Hasil pengujian diperoleh nilai $p$-value sig adalah $0,156>0,05$ artinya memenuhi asumsi manova. Maka hipotesis nol diterima yang aslinya matriks variankovarians antara kelompok model pembelajaran adalah homogen.

b. Homogenitas Varians

Tabel 7.

Hasil Uji Homogenitas Varians

\begin{tabular}{ccccc}
\hline \multicolumn{5}{c}{ Levene's Test of Equality of Error Variances } \\
\hline \\
Keterampilan Sosial & F & df1 & df2 & Sig. \\
Hasil Belajar Ekonomi & 2,279 & 1 & 62 &, 136 \\
\hline
\end{tabular}

Sumber : Hasil Output SPSS versi 20

Pengujian homogenitas varians menggunakan uji levene's. Persyaratan bahwa data homogenitas nilai signifikan > 0,05, maka hipotesis nol (Ho) diterima sesuai persyaratan. Hasil uji homogenitas terhadap 2 (dua) kelompok model pembelajaran untuk Keterampilan Sosial 0,136 > 0,05 dan Hasil Belajar Ekonomi 0,177 > 0,05.

\section{Uji Hipotesis}

Tabel Multivariate Tests menerangkan perbandingan rata-rata dan terdapat empat uji statistik yaitu Pillai's Trace, Wilk's Lambda, Hotteling's Trace, dan Ray's Largers (Suparman, 2014:289) dan biasanya keempat uji statistik tersebut menghasilkan kesimpulan yang sama (Sutrisno \& Wulandari, 2018:50). Pengujian hipotesis penelitian ini dilakukan dengan teknik analisis Manova (multivariate of varians) dengan bantuan program SPSS :

Tabel 8.

Uji MANOVA

\begin{tabular}{llccccc}
\hline & Effect & Value & F & Hypothesis df & Error df & Sig. \\
\hline \multirow{3}{*}{ Intercept } & Pillai's Trace &, 994 & 5429,928 & 2,000 & 61,000 &, 000 \\
& Wilks' Lambda &, 006 & 5429,928 & 2,000 & 61,000 &, 000 \\
& Hotelling's Trace & 178,030 & 5429,928 & 2,000 & 61,000 &, 000 \\
& Roy's Largest Root & 178,030 & 5429,928 & 2,000 & 61,000 &, 000
\end{tabular}




\begin{tabular}{lllllll} 
& Pillai's Trace &, 297 & 12,887 & 2,000 & 61,000 &, 000 \\
A & Wilks' Lambda &, 703 & 12,887 & 2,000 & 61,000 &, 000 \\
& Hotelling's Trace &, 423 & 12,887 & 2,000 & 61,000 &, 000 \\
& Roy's Largest Root &, 423 & 12,887 & 2,000 & 61,000 &, 000 \\
\hline \multicolumn{2}{l}{ Sumber : Hasil Output SPSS versi 20}
\end{tabular}

Selanjutnya, pada Tabel Tests of Between-Subjects Effects menurut Suparman (2014:291) menggambarkan pengujian model secara univariat.

Tabel 9.

Tests of Between-Subjects Effects

\begin{tabular}{llccccc}
\hline \multicolumn{1}{c}{ Source } & Dependent Variable & $\begin{array}{c}\text { Type III Sum of } \\
\text { Squares }\end{array}$ & df & Mean Square & F & Sig. \\
\hline Corrected & Keterampilan Sosial & $1914,062^{\mathrm{a}}$ & 1 & 1914,062 & 12,222 &, 001 \\
Model & Hasil Belajar Ekonomi & $689,062^{\mathrm{b}}$ & 1 & 689,062 & 8,710 &, 004 \\
Intercept & Keterampilan Sosial & 694722,250 & 1 & 694722,250 & 4436,062 &, 000 \\
& Hasil Belajar Ekonomi & 345156,250 & 1 & 345156,250 & 4363,109 &, 000 \\
A & Keterampilan Sosial & 1914,063 & 1 & 1914,063 & 12,222 &, 001 \\
& Hasil Belajar Ekonomi & 689,063 & 1 & 689,063 & 8,710 &, 004 \\
Error & Keterampilan Sosial & 9709,688 & 62 & 156,608 & & \\
& Hasil Belajar Ekonomi & 4904,688 & 62 & 79,108 & & \\
Total & Keterampilan Sosial & 706346,000 & 64 & & & \\
Corrected & Hasil Belajar Ekonomi & 350750,000 & 64 & & & \\
Total & Keterampilan Sosial & 11623,750 & 63 & & & \\
\hline Suasil Belajar Ekonomi & 5593,750 & 63 & & & &
\end{tabular}

Sumber : Hasil Output SPSS versi 20

1. Pengaruh Model Pembelajaran terhadap Keterampilan Sosial dan Hasil Belajar Ekonomi secara Multivariat

Terdapat pengaruh yang signifikan Model Pembelajaran terhadap Keterampilan Sosial dan Hasil Belajar Ekonomi secara multivariat. Berdasarkan hasil pengujian yang terdapat pada tabel Multivariate Test nilai Pillai's Trace, Wilks' Lambda, Hotelling's Trace,dan Roy's Largest Root sig sebesar 0,000 $(<0,05)$ dan Fh $=12,887$. Hal ini menunjukkan terdapat pengaruh yang signifikan Model Pembelajaran terhadap Keterampilan Sosial dan Hasil Belajar Ekonomi secara multivariat. Dalam hal ini Keterampilan Sosial dan Hasil Belajar Ekonomi pada kelompok eksperimen lebih tinggi daripada kelompok kontrol.

Variabel Keterampilan Sosial pada kelompok eksperimen lebih tinggi daripada kelompok kontrol karena dalam pelaksanaanya, model pembelajaran kooperatif tipe take and give para siswa mencari teman untuk saling bertukar informasi mengenai materi yang masing-masing mereka dapatkan dalam kartu. Model pembelajaran ini membuat siswa untuk dapat aktif dan bisa saling bekerja sama dalam mentransfer materi yang diterima, dan kemudian materi itu dibagikan kepada teman-temannya secara berulang. Dalam praktek model kooperatif sangat menjunjung tinggi nilai-nilai demokratis yang didasarkan pada kesepakatan kolektif antar anggota dalam setiap kelompok (Huda, 2013:112). Huda (2013) juga mengungkapkan bahwa pengaruh dari model pembelajaran kooperatif ini dapat membangkitkan antusias dan memberikan manfaat, serta menyeluruh, menyesuaikan antara tujuan penelitian akademik, integrasi sosial, pembelajaran, proses kolektif.

Variabel Hasil Belajar Ekonomi pada kelompok eksperimen lebih tinggi dibandingkan dengan kelompok kontrol adalah karena dalam prakteknya model pembelajaran kooperatif tipe take and give membawa suasana yang ceria, dinamis, dan semangat, serta menuntut keterampilan bekerja antar kelompok, berbagi 
informasi, dan evaluasi. Hasil penelitian ini sejalan dengan Septina (2018) yang menyatakan bahwa model pembelajaran tipe take and give efektif terhadap peningkatan hasil belajar, bersamaan dengan Septiana \& Ningrum (2017) yang juga menyatakan adanya pengaruh positif model pembelajaran tipe take and give terhadap hasil belajar. Selain itu, hasil penelitian ini juga didukung oleh Patonah (2018) yang menyatakan bahwa model pembelajaran tipe take and give dapat meningkatkan hasil belajar peserta didik. Teori lain yang mendukung hasil penelitian ini yaitu yang mengungkapkan bahwa salah satu faktor eksternal yang dapat mempengaruhi hasil belajar yaitu adalah pendekatan belajar atau metode mengajar seperti yang diungkapkan Hidayat (2013:85), Herawati (2017:108), dan Priansa (2017:44).

2. Pengaruh Model Pembelajaran terhadap Keterampilan Sosial

Terdapat pengaruh yang signifikan Model Pembelajaran terhadap Keterampilan Sosial. Berdasarkan hasil pengujian pada tabel Test of Between Subject Effects diatas yang merupakan tabel utama yang mempresentasikan hasil hipotesis yang diajukan peneliti. Dari tabel tersebut, diketahui nilai sig 0,001 $(<0,05)$ dan $F h=12,222$. Dengan demikian hipotesis nol ditolak atau terdapat perbedaan yang signifikan antara Keterampilan Sosial pada kelompok siswa yang diberi model pembelajaran kooperatif tipe take and give dengan Keterampilan Sosial pada siswa yang diberi model pembelajaran konvensional. Sehingga disimpulkan terdapat pengaruh yang signifikan Model Pembelajaran terhadap Keterampilan Sosial.

3. Pengaruh Model Pembelajaran terhadap Hasil Belajar Ekonomi

Terdapat pengaruh yang signifikan Model Pembelajaran terhadap Hasil Belajar Ekonomi. Berdasarkan hasil pengujian pada tabel Test of Between Subject Effects diketahui untuk kategori hasil belajar ekonomi (Y2) memiliki nilai sig 0,004 $(<0,05)$ dan $\mathrm{Fh}=8,710$. Dengan demikian hipotesis nol ditolak atau terdapat perbedaan yang signifikan antara Hasil Belajar Ekonomi siswa pada kelompok yang diberi model pembelajaran kooperatif tipe take and give dengan Hasil Belajar Ekonomi pada siswa yang diberi model pembelajaran konvensional. Sehingga disimpulkan terdapat pengaruh signifikan Model Pembelajaran terhadap Hasil Belajar Ekonomi.

\section{CONCLUSION}

Berdasarkan data yang diperoleh dari hasil pengujian hipotesis penelitian dan analisis pengolahan data, maka dapat disimpulkan :

1. Terdapat pengaruh yang signifikan Model Pembelajaran terhadap Keterampilan Sosial dan Hasil Belajar Ekonomi secara multivariat. Hal tersebut dibuktikan dengan nilai sig Pillai's Trace, Wilks' Lambda, Hotelling's Trace, dan Roy's Largest Root sig sebesar $0,000(<0,05)$ dan $\mathrm{Fh}=12,887$. Hal ini menunjukkan terdapat pengaruh yang signifikan Model Pembelajaran terhadap Keterampilan Sosial dan Hasil Belajar Ekonomi secara multivariat.

2. Terdapat pengaruh yang signifikan Model Pembelajaran terhadap Keterampilan Sosial. Hal tersebut dibuktikan dengan nilai sig 0,001 $(<0,05)$ dan $\mathrm{Fh}=12,222$. Hal ini menunjukkan terdapat pengaruh yang signifikan Model Pembelajaran terhadap Keterampilan Sosial.

3. Terdapat pengaruh yang signifikan Model Pembelajaran terhadap Hasil Belajar Ekonomi. Hal tersebut dibuktikan dengan nilai sig 0,004 $(<0,05)$ dan $\mathrm{Fh}=8,710$. Hal ini menunjukkan terdapat pengaruh yang signifikan model pembelajaran terhadap hasil belajar ekonomi. 


\section{REFERENCES}

Abidin, Zainal \& Fitriya L.H. (2018). Pengaruh Metode Pembelajaran Numbered Heads Together Terhadap Hasil Belajar Siswa MA Al-Muddatsiriyah Kemayoran Jakarta Pusat. Research and Development Journal of Education, 5(1), 11-24.

Agusniatih, Andi \& Monepa, J.M. (2019). Keterampilan Sosial Anak Usia Dini. Tasikmalaya : Edu Publisher.

Arifin, Zainal. (2011). Evaluasi Pembelajaran. Bandung : Remaja Rosdakarya.

Ekawati, Hanifah. (2016). Perbedaan Penerapan Model Pembelajaran Kooperatif Tipe Think-Pair-Share dan Pembelajaran Konvensional pada Kelas VII SMP Negeri 10 Samarinda, 1(1), 54-64.

Gayatri, Askardiya Mirza dan Septiana I.N. (2017). Peningkatan Minat Terhadap Hasil Belajar Peserta Didik Melalui Media Permainan Ular Tangga pada Pelajaran Kewirausahaan di Sekolah Menengah Kejuruan. Research and Development Journal of Education, 4(1), 88-100.

Herawati, Mirna. (2017). Penggunaan Metode Pembelajaran Think Pair and Share dalam Meningkatkan Hasil Belajar Mata Pelajaran IPS Kelas VI SDN Sawah 2 Ciputat. Research and Development Journal of Education, 3(2), 105-116.

Hidayat, Syarif. (2013). Teori dan Prinsip Pendidikan. Tangerang : Pusraka Mandiri.

Huda, Miftahul. (2013). Model-model Pengajaran dan Pembelajaran. Yogyakarta : Pustaka Pelajar.

Ibrahim. (2017). Perpaduan Model Pembelajaran Aktif Konvensional (Ceramah) dengan Cooperatif (Make-A Match) untuk Meningkatkan Hasil Belajar Pendidikan Kewarganegaraan. Suara Guru : Jurnal Ilmu Pendidikan Sosial, Sains, dan Humaniora, 3(2), 199-211.

Leksono, A. W., Vhalery, R., \& Maranatha, S. (2018). Cooperative Learning Model: The Power of Two Vs Tea Party. International Journal of Research \& Review (Www. Ijrrjournal. Com), 5(12), 80-88.

Lisdiana, Anita. (2019). Memantik Keterampilan Sosial Siswa Melalui Model Pembelajaran Two Stay-Two Stray (TS-TS). Jurnal Ilmiah Pendidikan, 3(2), 162182.

Mutakin, T.Z. \& Cleopatra, M. (2015). Suplemen Aplikasi Komputer dalam Penyusunan Karya Ilmiah. Tangerang : Pustaka Mandiri.

Patonah, Rita. (2018). Perbedaan Hasil Belajar Peserta Didik Model Pembelajaran Cooperative Learning Tipe Take and Give dan Tipe Treffinger Pelajaran Ekonomi. Faktor Jurnal Ilmiah Kependidikan, 5(2), 115-126.

Priansa, Donni J. (2017). Pengembangan Strategi dan Model Pembelajaran. Bandung : Pustaka Setia.

Putri, N.P.I.A., Pujani, N.M., \& Devi, N.L.P.L. (2019). Pengaruh Model Pembelajaran Kooperatif Tipe Think Pair Share Terhadap Keterampilan Sosial dan Prestasi Belajar Siswa SMP. Jurnal Pendidikan dan Pembelajaran Sains Indonesia Universitas Pendidikan Ganesha, 2(2), 92-103.

Rahayunngtyas, Dian Ikawati. (2018). Pengaruh Model Pembelajaran Inkuiri Terbimbing Terhadap Keterampilan Sosial dan Prestasi Belajar Siswa Kelas V SD. Jurnal PANCAR, 2(1), 32-41.

Saripah, I., \& Mulyani, L. (2015). Profil Keterampilan Sosial Siswa Sekolah Dasar Berdasarkan Latar Belakang Pendidikan Prasekolah (TK dan Non TK). Mimbar Sekolah Dasar ejournal Universitas Pendidikan Indonesia, 2(2), 152-166.

Septiana, Arin \& Ningrum. (2017). Pengaruh Penggunaan Model Cooperative Learning Tipe Take and Give Terhadap Hasil Belajar IPS Terpadu Siswa Kelas VIII 
Semester Genap SMP Muhammadiyah 1 Metro. Jurnal Pendidikan Ekonomi UM Metro, 5(1), 76-83.

Septina, Ria Karina Dwi. (2018). Pengaruh Model Pembelajaran Kooperatif Tipe Take and Give Terhadap Peningkatan Hasil Belajar Materi Perkalian Siswa Kelas 2 SDN Demangan Yogyakarta. E-Jurnal Prodi Teknologi Pendidikan, 7(3), 311-323.

Sugiyono. (2012). Metode Penelitian Kombinasi. Bandung: Alfabeta.

Suparman, I.A. (2014). Aplikasi Komputer dalam Penyusunan Karya Ilmiah. Tangerang : Pustaka Mandiri.

Sutrisno \& Wulandari, D. (2018). Multivariate Analysis of Variance (MANOVA) untuk Memperkaya Hasil Penelitian Pendidikan. Jurnal Aksioma Universitas PGRI Semarang, 9(1), 37-53.

Vhalery, R. (2019). Pengaruh Komitmen Belajar dan Lingkungan Kampus Terhadap Hasil Belajar Matematika Ekonomi. Lembaran Ilmu Kependidikan, 48(1), 18-22.

Vhalery, R., \& Martiah, A. (2018). Cooperative Learning in the Learning Activity of Students. International Journal of Scientific and Research Publications, 8(9), 62.

Vhalery, R., Sari, A. I. C., \& Yusup, A. A. M. (2020). PERBANDINGAN KETERAMPILAN SOSIAL MELALUI MODEL PEMBELAJARAN KOOPERATIF TIPE CI DAN CLS. Research and Development Journal of Education, 1(1), 60-71.

Yusuf, M., Tarjiah, I., \& Satibi, O. (2018). Penerapan Metode Simulasi untuk Meningkatkan Keterampilan Sosial Siswa dalam Pembelajaran IPS. Jurnal Tunas Bangsa Universitas Negeri Jakarta, 5(2), 124-132.

Zulyadaini. (2016). Perbandingan Hasil Belajar Matematika Model Pembelajaran Kooperatif Tipe Coop-coop dengan Konvensional. Jurnal Ilmiah Universitas Batanghari Jambi, 16(1), 153-158. 